\title{
PENGARUH MOTIVASI, GAYA KEPEMIMPINAN TRANSFORMASIONAL, DAN LINGKUNGAN KERJA FISIK TERHADAP SEMANGAT KERJA PEGAWAI
}

\author{
Pande Wayan Gede Suandana Putra ${ }^{1}$ \\ I Gusti Made Suwandana ${ }^{2}$
}

${ }^{1,2}$ Fakultas Ekonomi dan Bisnis Universitas Udayana (Unud), Bali, Indonesia E-mail:pandesuandana1@gmail.com ${ }^{1}$, gungdesuwandana@unud.ac.id ${ }^{2}$

\begin{abstract}
ABSTRAK
Tujuan penelitian adalah untuk mengetahui pengaruh motivasi, kepemimpinan transformasional, dan lingkungan kerja fisik terhadap semangat kerja pegawai Bappeda Litbang Provinsi Bali. Penelitian ini dilakukan di Bappeda Litbang Provinsi Bali. Jumlah sampel yang diambil sebanyak 83 orang pegawai, dengan metode sampel jenuh. Pengumpulan data diperoleh dari hasil penyebaran kuesioner. Analisis data menggunakan regresi linier berganda. Hasil dari penelitian adalah motivasi berpengaruh positif dan signifikan terhadap semangat kerja. Kepemimpinan transformasional berpengaruh positif dan signifikan terhadap semangat kerja. Lingkungan kerja fisik berpengaruh positif dan signifikan terhadap semangat kerja pegawai Bappeda Litbang Provinsi Bali. Hasil dalam penelitian ini tentunya dapat menjadikan pedoman bagi pimpinan Bappeda Litbang Provinsi Bali dan dapat memberikan peningkatan yang lebih spesifik terhadap semangat kerja. Memotivasi pegawai agar kinerja meningkat, mendengarkan keluhan para pegawai harus lebih rutin serta meningkatkan kenyamanan lingkungan kerja agar pegawai nyaman di saat bekerja untuk tercapainya tujuan dari organisasi.
\end{abstract}

Kata kunci:motivasi, gaya kepemimpinan transformasional, lingkungan kerja fisik, semangat kerja

\begin{abstract}
The purpose of the study was to determine the effect of motivation, transformational leadership, and physical work environment on the morale of employees of Bappeda Litbang Bali Province. This research was conducted at Bappeda Litbang Bali Province. The number of samples taken was 83 employees, with a saturated sample method. Data collection is obtained from the results of questionnaires. Data analysis using multiple linear regression. The results of the study are that motivation has a positive and significant effect on morale. Transformational leadership has a positive and significant effect on morale. The physical work environment has a positive and significant effect on the morale of employees of the Bappeda Litbang Bali Province. The results in this study certainly can make a guideline for the leadership of Bali Provincial $R \& D$ Bappeda and can provide a more specific increase in morale. Motivate employees to improve performance, listen to complaints from employees must be more routine and improve the comfort of the work environment so that employees are comfortable while working to achieve the goals of the organization.
\end{abstract}

Keywords: motivation, transformational leadership style, physical work environment, work spirit 


\section{PENDAHULUAN}

Sumber daya manusia sangat diperlukan untuk menunjang setiap aktivitas organisasi. Sumber daya manusia diharuskan untuk terus-menerus mengembangkan diri secara proaktif agar organisasi bisa bertahan dan bersaing dalam persaingan. Sumber daya manusia adalah salah satu sumber daya yang menentukan sukses tidaknya suatu organisasi (Ngambi, 2011). Faktor teknologi saja tidak cukup, sehingga investasi dalam sumber daya ekonomi yang paling berharga yaitu harus mengutamakan sumber daya manusia. Sumber daya manusia yang menduduki posisi sebagai atasan ataupun bawahan merupakan faktor penting dan salah satu kunci kesuksean dalam setiap organisasi. Atasan tidak ada, maka tidak ada yang mengatur jalannya organisasi begitu juga sebaliknya, jika tidak ada bawahan, maka atasan akan sulit untuk menjalankan organisasi.

Ardanadkk. (2012: 3) sumber daya manusia merupakan harta atau aset yang paling berharga dan paling penting yang dimiliki oleh suatu organisasi, keberhasilan organisasi sangat ditentukan oleh unsur manusia. Organisasi menuntut pegawai yang mempunyai kemampuan, tanggung jawab, serta loyalitas tinggi. Kondisi seperti ini juga menuntut setiap organisasi untuk mampu mempertahankan dan memelihara sumber daya manusianya dalam mencapai tujuan serta dapat menjalankan organisasi dengan efektif dan efisien. Sumber daya manusia harus dikelola dengan baik untuk meningkatkan efektivitas dan efisiensi organisasi, sebagai salah satu fungsi dalam organisasi.

Bappeda Litbang Provinsi Bali merupakan badan yang mempunyai tugas melaksanakan fungsi penunjangurusan pemerintahan yang menjadi kewenangan 
daerahprovinsi di bidang perencanaan, penelitian danpengembangan, serta melaksanakan tugas dekonsentrasisampai dengan dibentuk Sekretariat Gubernur sebagai WakilPemerintah Pusat dan melaksanakan tugas pembantuansesuai bidang tugasnya. Melihat daerah perencanaan, penelitian danpengembangan di setiap kabupaten di Provinsi Bali, maka instansi perlu memperhatikan faktor faktor yang mempengaruhi semangat kerja pegawai. Pegawai yang memiliki semangat kerja yang tinggi akan berusaha untuk mencapai tujuan organisasi setinggi mungkin.

Siagian (2007 : 42) menyatakan bahwa dengan meningkatnya semangat kerja maka pekerjaan akan lebih cepat diselesaikan, absensi dapat dikurangi, kerusakan barang akan dapat dikurangi, dan kemungkinan perpindahan pegawai dapat diperkecil. Arunchand (2013) semangat kerja pegawai adalah hubungan yang dimiliki pegawai atau sekelompok pegawai tertentu dengan pekerjaan mereka dan organisasi tempat mereka bekerja, semangat pegawai yang tinggi berarti pegawai senang, dan itu tercermin dalamjenis pekerjaan yang mereka hasilkan. Siagian (2007 : 57) menyatakan bahwa seorang pemimpin harus dapat mewujudkan bahkan meningkatkan semangat kerja pegawainya.

Kepemimpinan transformasional merupakan salah satu yang mempengaruhi semangat kerja. Northouse (2013:176) kepemimpinan transformasional adalah gaya kepemimpinan yang menekankan pada proses dimana orang terlibat dengan orang lain dan menciptakan suatu hubungan yang meningkatkan motivasi baik dalam diri pemimpin maupun pengikutnya. Anteja (2014) menyatakan bahwa 
Pande Wayan Gede Suandana Putra, Pengaruh Motivasi, Gaya...

gayakepemimpinan transformasional berpengaruh positif dan signifikan terhadap semangat kerja pegawai.

Motivasi merupakan faktor yang mempengaruhi semangat kerja.Motivasi merupakan kegiatan yang menyalurkan, mengakibatkan sampai memelihara perilaku manusia (Robins, 2006: 251). Yordy (2016) memotivasi pegawai sangat dibutuhkan untuk dapat meningkatkan semangat kerja pegawai, tanpa adanya motivasi, pegawai tersebut tidak memiliki semangat dalam bekerja serta dorongan dalam melakukan segala tugas yang diberikan. Utamajaya (2015) menemukan dalam penelitiannya bahwa secara simultan motivasi berpengaruh positif signifikan terhadap semangat kerja pegawai

Lingkungan kerja fisik merupakan faktor lain yang mempengaruhi semangat kerja. Lingkungan kerja fisik yang baik akan membawa kenyamanan dalam bekerja sehingga akan meningkatkan semangat kerja pegawai (Utamajaya, 2015). Anwar (2013) menyebutkan Lingkungan kerja yang baik akan mendorong timbulnya semangat kerja pegawai. Dengan semangat kerja yang tinggi, pegawai akan dapat bekerja dengan perasaan senang dan bergairah sehingga mereka akan berprestasi dalam pekerjaanya, lingkungan kerja merupakan segala sesuatu yang ada disekitar para pekerja yang dapat mempengaruhi dirinya dalam menjalankan tugas-tugas yang dikerjakan untuk meningkatkan kepuasan dan semangat kerja. (Nitisemito, 2000:183). Didalam menciptakan lingkungan kerja fisik agar dapat meningkatkan aktivitas organisasi, maka diperlukan pengaturan lingkungan kerja fisik seperti : ruangan, penerangan, keadaan udara, warna, kebisingan, kebersihan, dan keamanan (Sedarmayanti, 2001:21). Utamajaya (2015) menyatakan bahwa 
secara simultan lingkungan kerja fisik berpengaruh positif signifikan terhadap semangat kerja pegawai

Bappeda Litbang Provinsi Bali adalah salah satu instansi pemerintah di Bali.Sebanyak 83 pegawai yang terdiri dari sekretaris, kepala bidang, kepala sub bidang, kepala sub bagian dan staff, bidang-bidang ini memiliki tanggung jawab dan beban kerja yang bervariasi sehingga dibutuhkan SDM yang berkualitas dan bersemangat tinggi dalam rangka mencapai tujuan organisasi. Banyaknya tanggung jawab dan beban kerja yang tinggi akan membuat pegawai tidak semangat dalam bekerja.

Berikut ini merupakan uraian indikator yang menunjukkan bahwa terdapat permasalahan pada semangat kerja yang diperoleh berdasarkan hasil wawancara terhadap 10 pegawai dengan berpedoman pada indikator semangat kerja.

\section{Tabel 1.}

Semangat Kerja Pegawai Bappeda Litbang Provinsi Bali Tahun 2018

\begin{tabular}{clcccccc}
\hline No & \multicolumn{1}{c}{ Daftar Pertanyaan } & SS & S & N & TS & STS & Jumlah \\
\hline 1 & Tingkat kehadiran saya sudah baik & 0 & 2 & 4 & 4 & 0 & 10 \\
2 & $\begin{array}{l}\text { Pekerjaan yang saya lakukan selesai tepat } \\
\text { waktu }\end{array}$ & 2 & 2 & 2 & 4 & 0 & 10 \\
3 & $\begin{array}{l}\text { Saya tidak meninggalkan pekerjaan saat } \\
\text { jam kerja }\end{array}$ & 1 & 2 & 2 & 5 & 0 & 10 \\
4 & $\begin{array}{l}\text { Saya melaksanakan pekerjaan sesuai } \\
\text { dengan instruksi atasan }\end{array}$ & 3 & 2 & 2 & 3 & 0 & 10 \\
5 & $\begin{array}{l}\text { Saya puas dengan pembagian kerja yang } \\
\text { dilakukan }\end{array}$ & 1 & 2 & 2 & 3 & 2 & 10 \\
Jumlah & $\mathbf{7}$ & $\mathbf{1 0}$ & $\mathbf{1 2}$ & $\mathbf{1 9}$ & $\mathbf{2}$ & \\
\hline
\end{tabular}

Sumber :Hasil wawancara pegawai Bappeda Litbang Provinsi Bali, 2018

Keterangan:

STS = Sangat Tidak Setuju diberi skor 1

TS = Tidak Setuju diberi skor 2

$\mathrm{N} \quad=$ Netral diberi skor 3

$\mathrm{S} \quad=$ Setuju diberi skor 4 
Pande Wayan Gede Suandana Putra, Pengaruh Motivasi, Gaya...

SS = Sangat Setuju diberi skor 5

Berdasarkan Tabel 1 dapat dilihat bahwa jawaban pegawai adalah cenderung berada pada skor tidak setuju, sehingga hal ini mengindikasikan ada pegawai yang memiliki semangat kerja yang rendah dan perlu diketahui penyebabnya berdasarkan indikator - indikator yang sesuai. Motivasi pada Bappeda Litbang Provinsi Bali terdapat permasalahan, dari hasil observasi terdapat masih adanya pegawai yang melanggar peraturan seperti meninggalkan tempat kerja pada saat jam kerja, tentunya ini tidak sesuai dengan indikator motivasi George dan Jones (2005:175) yaitu pegawai selalu menanti peraturan yang ditetapkan oleh perusahaan.

Teori kepemimpinan transformasional terdiri dari empat komponen inti yang selalu melekat di dalamnya, yaitu pengaruh yang diidealkan (kharisma), motivasi yang inspiratif, stimulasi intelektual, dan pertimbangan individual. Pengaruh yang diidealkan dalam hal ini berarti pemimpin berperilaku dengan cara mempengaruhi pengikut mereka sehingga pengikut dapat mengagumi dan menghormati pemimpinnya. Motivasi yang inspiratif dalam hal ini pemimpin transformasional memberikan motivasi dan menginspirasi orang - orang disekitar mereka dengan memberikan arti dan tantangan untuk bekerja. Stimulasi intelektual berarti pemimpin mendorong upaya pengikut untuk menjadi inovatif dan kreatif sehingga dapat menyelesaikan masalah lama dengan perspektif baru. Pertimbangan individual dalam hal ini pemimpin memberikan perhatian khusus terhadap kebutuhan masing - masing individu untuk dapat berkembang dan berprestasi dengan bertindak sebagai mentor, pelatih, ataupun fasilitator. 
Teori gaya kepemimpinan transformasional digunakan dalam penelitian ini karena di dalam teori ini dijelaskan bahwa pemimpin transformasional memberikan motivasi dan menginspirasi orang - orang disekitar mereka dengan memberikan semangat, arti dan tantangan untuk bekerja. Kepemimpinan di dalam penelitian ini berhubungan kuat dengan motivasi yang didapat pegawai dalam melakukan pekerjaan. Pengaruh yang diidealkan dalam hal ini berarti pemimpin berperilaku dengan cara mempengaruhi pengikut mereka, sehingga pengikut dapat mengagumi dan menghormati pemimpinnya.

Semangat kerja merupakan kegiatan melakukan pekerjaan secara lebih giat, dengan hal tersebut diharapkan apapun pekerjaan yang dilakukan dapat lebih cepat diselesaikan dan akhirnya akan memperoleh hasil yang memuaskan (Nitisemito, 2000 : 96). Tohardi (2006 : 427) semangat kerja merupakan sekelompok orang yang memiliki kemampuan untuk melakukan kerjasama secara konsekuen dan giat dalam hal mengejar tujuan yang telah ditetapkan bersama.

Maduka (2014) menyatakan motivasi adalah suatu proses dalam diri manusia yang menghasilkan dorongan berupa aksi dan reaksi. Saraswathi (2011) menyatakan bahwa motivasi didefinisikan sebagai kesediaan untuk mengerahkan tingkat tinggi usaha menuju tujuan organisasi yang di kondisikan oleh upaya dan kemampuan untuk memenuhi beberapa kebutuhan individual. Ardana dkk. (2012) menyatakan motivasi adalah kekuatan yang mendorong seseorang untuk melakukan suatu tindakan atau tidak pada hakekatnya secara internal dan eksternal yang dapat positif atau negatif untuk mengarahkannya yang sangat bergantung kepada ketangguhan sang manajer. 
Prabu (2005) menyatakan motivasi adalah hal yang menyebabkan dan mendukung perilaku manusia, supaya mau bekerja giat dan antusias mencapai hasil yang optimal. Gorda (2004:176) menyatakan motivasi merupakan serangkaian dorongan yang dirumuskan secara sengaja oleh pimpinan perusahaan yang ditujukan kepada pegawai agar mereka bersedia secara ikhlas melakukan prilaku tertentu yang berdampak pada peningkatan prestasi kerja dalam rangka pencapaian tujuan perusahaan yang telah ditetapkan sebelumnya.

Gaya kepemimpinan transformasional adalah gaya kepemimpinan yang menginspirasi para pengikut untuk melampaui kepentingan diri sendiri demi kepentingan perusahaan (Robbins dan Judge, $2015: 249$ ). Northouse (2013:176)kepemimpinan transformasional adalah sebuah gaya kepemimpinan yang menekankan pada proses dimana orang terlibat dengan orang lain dan menciptakan suatu hubungan yang meningkatkan motivasi baik dalam diri pemimpin maupun pengikutnya. Gunawan dan Netra (2017) berpendapat bahwa kepemimpinan transformasional cenderung memberikan perhatian lebih kepada para pengikutnya. Ljungholm (2014) menyatakan bahwa kepemimpinan transformasional dapat meningkatkan kinerja karyawan, manajer harus menunjukkan kepemimpinan transformasional dan terlibat langsung dalam hubungan dengan karyawan mereka. Dewi dan Mujiati (2015) menyatakan gaya kepemimpinan transformasional adalah gaya kepemimpinan yang inspiratif, dapat meningkatkan kinerja karyawan, dan dapat bertindak sebagai pemimpin yang efektif. Rahmi (2014) menyatakan bahwa pemimpin yang menerapkan kepemimpinan transformasional memberikan pengaruh kepada para pengikutnya 
untuk berpartisipasi dalam pencapaian tujuan, pemecahan masalah dan pengambilan keputusan.

Mangkunegara (2005:17) lingkungan kerja yang dimaksudantara lain uraian jabatan yang jelas, target kerja yang menantang, pola komunikasi kerjayang efektif, iklim kerja dan fasilitas kerja yang relatif memadai. Lingkungan kerja terdiridari lingkungan fisik dan nonfisik yang melekat pada pegawai sehingga tidak dapatdipisahkan untuk mendapatkan kinerja pegawai yang baik.Sedarmayanti (2009:31) lingkungan kerja fisik adalah semua keadaanberbentuk fisik yang terdapat di sekitar tempat kerja yang dapat mempengaruhi pegawaibaik secara langsung maupun secara tidak langsung.

Robbins (2006: 36) Lingkungan kerja fisik juga merupakan faktor penyebab strees kerja pegawai yang berpengaruh pada prestasi kerja. Faktorfaktor yang mempengaruhi lingkungan kerja fisik adalah: 1) Suhu. Suhu adalah suatu variabel dimana terdapat perbedaan individual yang besar. Dengan demikian untuk memaksimalkan produktivitas, adalah penting bahwa pegawai bekerja di suatu lingkungan dimana suhu diatur sedemikian rupa sehingga berada diantara rentang kerja yang dapat diterima setiap individu. 2) Kebisingan. Bukti dari telaah-telaah tentang suara menunjukkan bahwa suara-suara yang konstan atau dapat diramalkan pada umumnya tidak menyebabkan penurunan prestasi kerja sebaliknya efek dari suara-suara yang tidak dapat diramalkan memberikan pengaruh negatif dan mengganggu konsentrasi pegawai. 3) Penerangan. Bekerja pada ruangan yang gelap dan samar-samar akan menyebabkan ketegangan pada mata. Intensitas cahaya yang tepat dapat membantu pegawai dalam memperlancar 
Pande Wayan Gede Suandana Putra, Pengaruh Motivasi, Gaya...

aktivitas kerjanya. Tingkat yang tepat dari intensitas cahaya juga tergantung pada usia pegawai. Pencapaian prestasi kerja pada tingkat penerangan yang lebih tinggi adalah lebih besar untukpegawai yang lebih tua dibanding yang lebih muda. 4) Kualitas Udara. Merupakan fakta yang tidak bisa diabaikan bahwa jika menghirup udara yang tercemar membawa efek yang merugikan pada kesehatan pribadi. Udara yang tercemar dapat mengganggu kesehatan pribadi pegawai. Udara yang tercemar di lingkungan kerja dapat menyebabkan sakit kepala, mata perih, kelelahan, lekas marah dan depresi.

Utamajaya (2015) menemukan bahwa motivasi berpengaruh signifikan terhadap semangat kerja pegawai, arah yang ditujukkan arah positif. Ini berarti bahwa motivasi yang diberikan kepada pegawai dapat meningkatkan semangat kerja pegawai. Yordy(2016) dan Purnamandari (2014) menemukan dalam penelitiannya bahwa motivasi berpengaruh positif terhadap semangat kerja. Kusuma dkk. (2017) dalam penelitiannya mengungkapkan motivasi berpengaruh positif signifikan terhadap semangat kerja pegawai di Dinas Kesehatan Kabupaten Tabanan. Buroidah (2014) menyatakan dalam penelitiannya yaitu motivasi berpengaruh signifikan terhadap variabel dependen yaitu Semangat Kerjapada guru dan pegawai SMK Pancasila 1 Kutoarjo. Berdasarkan studi empiris tersebut, hipotesis penelitiannya adalah sebagai berikut.

$\mathrm{H}_{1}$ :Motivasi berpengaruh positif dan signifikan terhadap semangat kerja pegawai

Penelitian Rashmi (2015), Purnamandari dkk. (2014) dan Paryudi dkk. (2014) menyatakan bahwa gaya kepemimpinan transformasional berpengaruh positifdan signifikan terhadap semangat kerja. Selain itu Penelitian Ari dkk. 
(2012) dan Stewart et al. (2015) menyatakan bahwa gaya kepemimpinan transformasional secara parsial menjadi variabel yang mampu meningkatkan semangat kerja pegawai. Berdasarkan studi empiris tersebut, hipotesis penelitiannya adalah sebagai berikut.

$\mathrm{H}_{2}$ : Gaya kepemimpinan transformasional berpengaruh positif dan signifikan terhadap semangat kerja pegawai.

Utamjaya(2015) di dalam penelitinnya menyatakan bahwa lingkungan kerja fisik berpengaruh signifikan terhadap semangat kerja pegawai, dengan arah pengaruh arah positif. Ini berarti bahwa semakin baik lingkungan kerja fisik maka akan semakin meningkatkan semangat kerja pegawai. Penelitian yang dilakukan oleh Suwardikaet al. (2015) menyatakan bahwa lingkungankerja fisik secara simultan berpengaruh signifikan terhadap semangat kerja pegawai.Anwar (2013) menyatakan lingkungn kerja berpengaruh terhadap semangat kerja pegawai kantor imigrasi kelass I kota samarinda. Paryudi (2014) dan Agustina (2016) menyatakan pula bahwa terdapat hubungan yang positiv signifikan antara lingkungan kerja fisik dengan semangat kerja pegawai. Berdasarkan studi empiris tersebut, hipotesis penelitiannya adalah sebagai berikut.

$\mathrm{H}_{3}$ : Lingkungan kerja fisik berpengaruh positif dan signifikan terhadap semangat kerja pegawai.

\section{METODE PENELITIAN}

Penelitian ini dilakukan di Bappeda Litbang Provinsi Bali yang beralamat di Jalan Cokorda Agung Tresna, Kota Denpasar, Bali 80239, Indonesia.

Populasi dalam penelitian ini adalah seluruh pegawai Bappeda Litbang Provinsi Bali yang berjumlah 83 orang. Metode yang digunakan dakam penentuan sampel adalah metode sampel jenuh yaitu, seluruh pegawai dalam populasi 
Pande Wayan Gede Suandana Putra, Pengaruh Motivasi, Gaya...

sejumlah 83 orang akan diteliti karena jumlahnya tidak terlalu besar. Berikut adalah data jumlah dan jabatan pegawai di Bappeda Litbang Provinsi Bali. 
Tabel 2.

Indikator dan pernyataan variabel Semangat Kerja (Y)

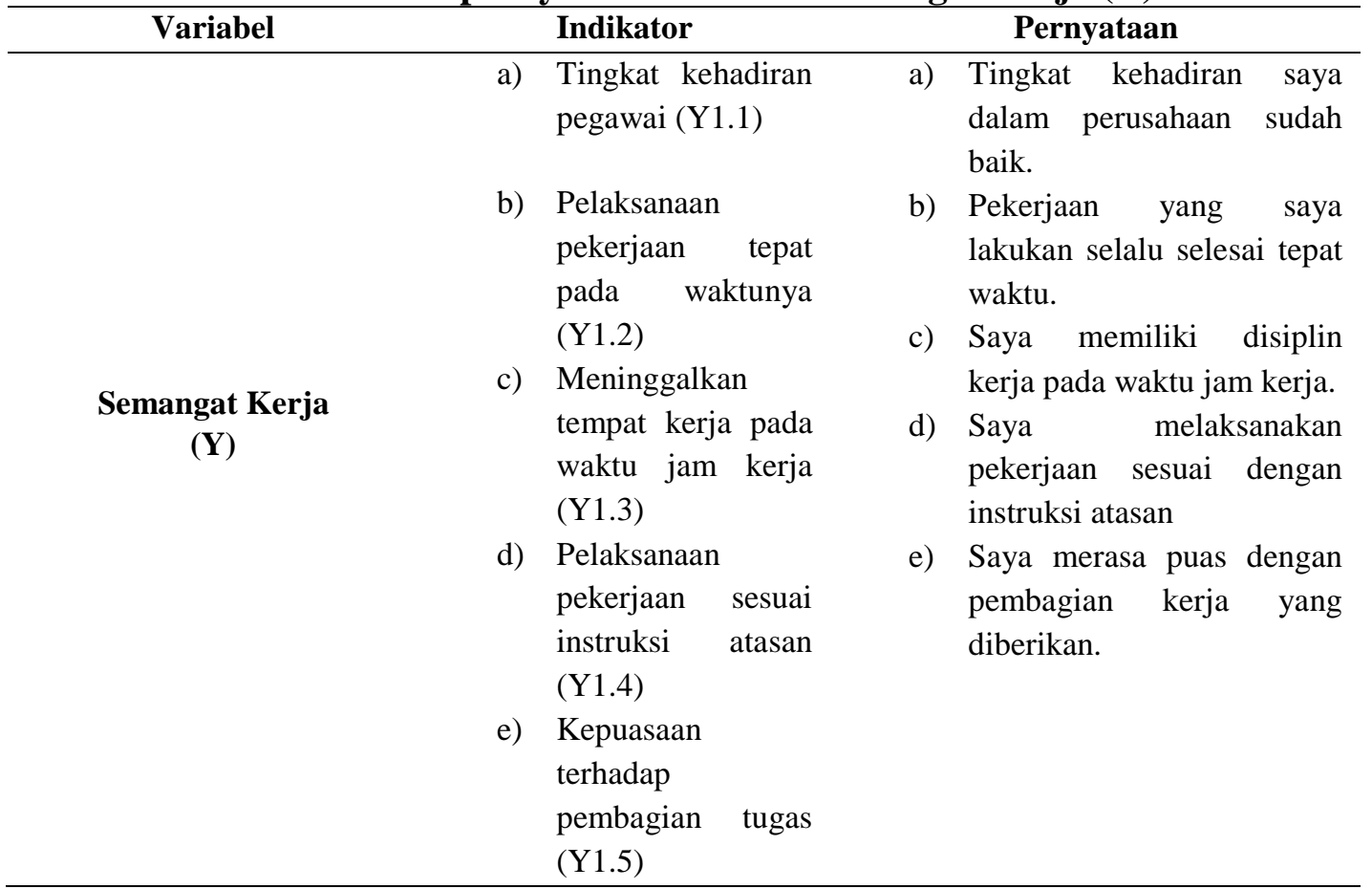

Sumber: Tohardi,2006: 427

Tabel 3.

Indikator dan pernyataan variabel Motivasi $\left(\mathbf{X}_{1}\right)$

\begin{tabular}{|c|c|c|c|c|}
\hline Variabel & & Indikator & Per & tanyaan dalam kuisioner \\
\hline \multirow[t]{3}{*}{ Motivasi (X1) } & a) & $\begin{array}{l}\text { Arah perilaku } \\
\text { (direction of } \\
\text { behavior) }\left(\mathrm{X}_{1.1}\right)\end{array}$ & a) & $\begin{array}{l}\text { Saya selalu mentaati } \\
\text { peraturan yang ditetapkan } \\
\text { oleh perusahaan }\end{array}$ \\
\hline & b) & $\begin{array}{l}\text { Tingkat usaha (level } \\
\text { of effort) }\left(\mathrm{X}_{1.2}\right)\end{array}$ & b) & $\begin{array}{l}\text { Saya selalu berusaha serius } \\
\text { pada pekerjaan yang selalu } \\
\text { saya lakukan }\end{array}$ \\
\hline & c) & $\begin{array}{l}\text { Tingkat kegigihan } \\
\text { (level of persistence) } \\
\left(\mathrm{X}_{1.3}\right)\end{array}$ & c) & $\begin{array}{l}\text { Saat saya melakukan } \\
\text { kesalahan dalam melakukan } \\
\text { pekerjaan, saya akan } \\
\text { berinisiatif memperbaiki } \\
\text { menjadi lebih baik }\end{array}$ \\
\hline
\end{tabular}

Sumber: George dan Jones, 2005:175

Uji hipotesis melalui analisis regresi linier berganda dilakukan untuk mengetahui ketergantungan variabel terikat dengan satu atau lebih variabel bebas. Analisis regresi linier berganda digunakan karena mampu menginterpretasikan hubungan linier antara motivasi, gaya kepemimpinan transformasional, 
lingkungan kerja fisik, dan semangat kerja. Dalam analisis peneliti dibantu dengan program SPSS for Windows.

$\mathrm{Y}=\alpha+\beta_{1} \mathrm{X}_{1}+\beta_{2} \mathrm{X}_{2}+\beta_{3} \mathrm{X}_{3}+\mathrm{i}$

Dimana:

$\mathrm{Y} \quad=$ Semangat kerja

$\alpha \quad=$ konstanta

$\mathrm{X}_{1} \quad=$ Motivasi

$\mathrm{X}_{2} \quad$ = Gaya kepemimpinan transformasional

$\mathrm{X}_{3} \quad=$ Lingkungan kerja fisik

$\beta_{1}-\beta_{3}=$ Koefisien regresi

$\mathrm{i} \quad=$ Variabel Pengganggu (residual error)

Penggunaan analisis regresi linier berganda mampu menjelaskan serta menginterpretasikan hubungan linier dari motivasi, gaya kepemimpinan transformasional, lingkungan kerja fisik dan semangat kerja.

Tabel 4.

Indikator dan pernyataan variabel Gaya Kepemimpinan Transformasional $\left(\mathbf{X}_{2}\right)$

\begin{tabular}{|c|c|c|c|c|}
\hline Variabel & \multicolumn{2}{|r|}{ Indikator } & \multicolumn{2}{|c|}{ Pertanyaan dalam kuisioner } \\
\hline \multirow{5}{*}{$\begin{array}{c}\text { Kepemimpinan } \\
\text { Transformasional (X2) }\end{array}$} & a) & $\begin{array}{l}\text { Pengaruh idealis } \\
\left(\mathrm{X}_{2.1}\right)\end{array}$ & a) & $\begin{array}{l}\text { Saya menghormati } \\
\text { pimpinan }\end{array}$ \\
\hline & b) & $\begin{array}{l}\text { Motivasi yang } \\
\text { memberi inspirasi }\end{array}$ & b) & $\begin{array}{l}\text { Pimpinan memberikan saya } \\
\text { tantangan }\end{array}$ \\
\hline & & $\left(X_{2.2}\right)$ & c) & Pimpinan mempunyai ide \\
\hline & c) & $\begin{array}{l}\text { Stimulasi intelektual } \\
\left(\mathrm{X}_{2.3}\right)\end{array}$ & & $\begin{array}{l}\text { kreatif dalam solusi } \\
\text { pekerjaan }\end{array}$ \\
\hline & d) & $\begin{array}{l}\text { Pertimbangan } \\
\text { individu }\left(\mathrm{X}_{2.4}\right)\end{array}$ & d) & $\begin{array}{l}\text { Pimpinan mendengarkan } \\
\text { keluhan pegawai }\end{array}$ \\
\hline
\end{tabular}

Sumber: Bass, 1985:49

Tabel 5.

Indikator dan pernyataan variabel Lingkungan Kerja (X3) Variabel Indikator Pernyataan

a) Penerangan di tempat $\operatorname{kerja}\left(\mathrm{X}_{4.1}\right)$

b) Keadaan udara di tempat kerja $\left(\mathrm{X}_{4.2}\right)$

a) Cahaya untuk penerangan sudah memadai. 
Lanjutan Tabel 5.Indikator dan pernyataan variabel Lingkungan Kerja (X3)

\begin{tabular}{|c|c|c|c|c|}
\hline Variabel & & Indikator & & Pernyataan \\
\hline Lingkungan Kerja (X4) & $\begin{array}{l}\text { c) } \\
\text { d) } \\
\text { e) } \\
\text { f) } \\
\text { g) }\end{array}$ & $\begin{array}{l}\text { Tingkat kebisingan } \\
\left(\mathrm{X}_{4.3}\right) \\
\text { Kebersihan } \\
\text { lingkungan tempat } \\
\text { bekerja }\left(\mathrm{X}_{4.4}\right) \\
\text { Tata warna tempat } \\
\text { kerja }\left(\mathrm{X}_{4.5}\right) \\
\text { Ruang gerak }\left(\mathrm{X}_{4.6}\right) \\
\text { Keamanan } \\
\text { Lingkungan }\left(\left(\mathrm{X}_{4.7}\right)\right.\end{array}$ & $\begin{array}{l}\text { f) } \\
\text { g) }\end{array}$ & $\begin{array}{l}\text { Saya merasa suhu } \\
\text { udara di tempat kerja } \\
\text { sudah baik. } \\
\text { Saya merasa suasana } \\
\text { di tempat kerja jauh } \\
\text { dari kebisingan. } \\
\text { Lingkungan tempat } \\
\text { saya bekerja nyaman } \\
\text { dan bersih } \\
\text { Penempatan tata } \\
\text { warna di tempat kerja } \\
\text { sudah baik. } \\
\text { Saya merasa memiliki } \\
\text { ruang gerak yang } \\
\text { bmencukupi . } \\
\text { Saya merasa aman di } \\
\text { tempat kerja }\end{array}$ \\
\hline
\end{tabular}

Sumber: Ahyari, 2007:149

\section{HASIL DAN PEMBAHASAN}

Karakteristik responden dapat diuraikan sebagai berikut.

Tabel 6.

Karakteristik Responden Berdasarkan Jenis Kelamin di Bappeda Litbang Provinsi Bali

\begin{tabular}{ccccc}
\hline No. & Jenis Kelamin & Jumlah (Orang) & Persentase (\%) \\
\hline 1 & Laki-laki & 50 & 60,24 & \\
2 & Perempuan & 33 & 39,76 & $\mathbf{1 0 0}$ \\
& Total & $\mathbf{8 3}$ & & $\mathbf{1 0 0}$ \\
\hline
\end{tabular}

Sumber:Data diolah, 2018

Tabel 6 menjelaskan jenis kelamin pada karyawan laki-laki sebanyak 50 orang dan karyawan perempuan sebanyak 33 orang dengan persentase masingmasing sebesar 60,24 persen pada karyawan laki-laki dan 39,76 persen pada karyawan perempuan. Artinya sebagian besar pegawai Bappeda Litbang Provinsi Bali mempergunakan tenaga laki-laki untuk menyelesaikan tugas-tugas. 
Tabel 7 menunjukkan bahwa sebagian besar responden berusia di antara 4954 tahun dengan persentase 30,12 persen, sedangkan untuk kelompok usia terendah yaitu pada usia 25-30 tahun dengan persentase 6,02 persen.

Tabel 7.

Karakteristik Responden Berdasarkan Usia di Bappeda Litbang Provinsi Bali

\begin{tabular}{cccc}
\hline No. & Usia & Jumlah (Orang) & Persentase (\%) \\
\hline 1 & $25-30$ & 5 & 6,02 \\
2 & $31-36$ & 7 & 8,43 \\
3 & $37-42$ & 14 & 16,87 \\
4 & $43-48$ & 23 & 27,71 \\
5 & $49-54$ & 25 & 30,12 \\
6 & $55-60$ & 9 & 10,84 \\
& Total & $\mathbf{8 3}$ & $\mathbf{1 0 0}$ \\
\hline
\end{tabular}

Sumber:Data diolah, 2018

Tabel 8.

Karakteristik Responden Berdasarkan Pendidikan Terakhir di Bappeda Litbang Provinsi Bali

\begin{tabular}{cccc}
\hline No. & Pendidikan Terakhir & Jumlah (Orang) & Persentase (\%) \\
\hline 1 & SMA & 12 & 14,46 \\
2 & Diploma & 10 & 12,05 \\
3 & Sarjana (S.1) & 42 & 50,60 \\
4 & Pasca Sarjana (S.2) & 19 & 22,89 \\
\hline & Total & $\mathbf{8 3}$ & $\mathbf{1 0 0}$ \\
\hline
\end{tabular}

Sumber: Data diolah, 2018

Tabel 8 menunjukkan bahwa tingkat pendidikan terakhir di Bappeda Litbang Provinsi Bali sebagian besar sarjana yang berjumlah 42 orang dengan persentase 50,60 persen dan hanya 12 orang tingkat pendidikannya SMA dengan persentase 14,46 persen.

Tabel 9 menunjukkan bahwa sebagian besar responden memiliki pengalaman bekerja selama > 20-30 tahun sebanyak 35 orang atau 42,17 persen, sedangkan pengalaman bekerja $>30-40$ tahun adalah pengalaman bekerja yang paling sedikit dimiliki oleh pegawai Bappeda Litbang Provinsi Bali sebanyak 4 orang yaitu 4,82 persen. 
Hasil analisis regresi linier berganda seperti yang ditunjukkan pada Tabel 10, maka persamaan regresinya adalah sebagai berikut.

$$
Y=0,500 X_{1}+0,546 X_{2}+0,315 X_{3}+2,017
$$

Persamaan regresi linier berganda di atas diketahui bahwa koefisien regresi dari variabel motivasi sebesar 0,500 dan bertanda positif yang berarti apabila terjadi peningkatan sebesar satu satuan, maka akan menyebabkan meningkatnya semangat kerja sebesar 0,500 dengan asumsi variabel yang lain dalam persamaan ini konstan.

Tabel 9.

Karakteristik Responden Berdasarkan Masa Kerja Pegawai Bappeda Litbang Provinsi Bali

\begin{tabular}{cccc}
\hline No. & Lama Bekerja & Jumlah (Orang) & Persentase (\%) \\
\hline 1 & $<10$ Tahun & 12 & 14,46 \\
2 & 10-20 Tahun & 32 & 38,55 \\
3 & $>$ 20-30 Tahun & 35 & 42,17 \\
4 & $>$ 30-40 Tahun & 4 & 4,82 \\
& Total & $\mathbf{8 3}$ & $\mathbf{1 0 0}$ \\
& & & \\
\hline
\end{tabular}

Sumber:Data diolah, 2018

Tabel 10.

Hasil Uji Analisis Regresi Linier Berganda

\begin{tabular}{|c|c|c|c|c|c|}
\hline \multirow{2}{*}{ Model } & \multicolumn{2}{|c|}{ Unstandardized Coefficients } & \multirow{2}{*}{$\begin{array}{c}\text { Standardized } \\
\text { Coefficients }\end{array}$} & \multirow{2}{*}{$\mathbf{t}$} & \multirow{2}{*}{ Sig. } \\
\hline & B & $\begin{array}{l}\text { Std. } \\
\text { Error }\end{array}$ & & & \\
\hline & $-6,223$ & 2,017 & & $-3,085$ & 0,003 \\
\hline Motivasi & 0,500 & 0,131 & 0,274 & 3,806 & 0,000 \\
\hline Gaya & & & & & \\
\hline Kepemimpinan & 0,546 & 0,099 & 0,414 & 5,532 & 0,000 \\
\hline Transformasional & & & & & \\
\hline $\begin{array}{l}\text { Lingkungan Kerja } \\
\text { Fisik }\end{array}$ & 0,315 & 0,078 & 0,328 & 4,026 & 0,000 \\
\hline R Square & & & & & 0,741 \\
\hline F Stastistik & & & & & 76,105 \\
\hline Signifikansi & & & & & 0,000 \\
\hline
\end{tabular}


Persamaan regresi linier berganda di atas diketahui bahwa koefisien regresi dari variabel gaya kepemimpinan transformasional sebesar 0,546 dan bertanda positif yang berarti bahwa apabila terjadi peningkatan sebesar satu satuan, maka akan menyebabkan meningkatnya semangat kerja sebesar 0,546 dengan asumsi variabel yang lain dalam persamaan ini konstan.

Persamaan regresi linier berganda di atas diketahui bahwa koefisien regresi dari variabel lingkungan kerja fisik sebesar 0,315 dan bertanda positif yang berarti bahwa apabila terjadi peningkatan sebesar satu satuan, maka akan menyebabkan meningkatnya semangat kerja sebesar 0,315 dengan asumsi variabel yang lain dalam persamaan ini konstan.

Menguji signifikansi variabel independen motivasi (X1), gaya kepemimpinan transformasional (X2), lingkungan kerja fisik (X3) secara serempak terhadap variabel dependen semangat kerja (Y) Bappeda Litbang Provinsi Bali.

Besarnya nilai Adjusted $R$ Square sebesar 0,624. Hal ini mengindikasikan bahwa kontribusi motivasi, gaya kepemimpinan transformasional, dan lingkungan kerja fisik sebesar 0,741 yang berarti besar pengaruh variabel bebas terhadap variabel terikatnya adalah $0,741 \times 100 \%=74,1 \%$, sedangkan sebesar $25,9 \%$ dijelaskan oleh faktor-faktor lainnya yang tidak diuji dalam penelitian ini.

Berdasarkan tabel di atas Hasil Uji F dapat dilihat nilai signifikan yakni 0,000 kurang dari $0,05(0,000<0,05)$ dengan nilai $\mathrm{F}$ hitung sebesar 76,105 dan nilai $\mathrm{F}$ tabel yang diperoleh dari tabel $\mathrm{F}$ dengan derajat kebebasan $\mathrm{N}-\mathrm{k}=83-4$ $=79$ dan $\mathrm{k}-1=4-1=3$, sehingga diperoleh nilai $\mathrm{F}$ tabel sebesar 2,72. Karena $\mathrm{F}$ 
hitung $>\mathrm{F}_{\text {table }}(76,105>2,72)$ Sehingga $\mathrm{H}_{0}$ ditolak. Dengan kata lain Paling sedikit salah satu dari variabel motivasi, gaya kepemimpinan transformasional, dan lingkungan kerja fisik secara simultan tidak berpengaruh signifikan terhadap semangat kerja pegawai Bappeda Litbang Provinsi Bali.

Tabel 11.

Hasil Uji F

\begin{tabular}{clccccc}
\hline & & Sum of & & Mean & & \\
& Model & Squares & df & Square & F & Sig. \\
\hline \multirow{2}{*}{1} & Regression & 298.427 & 3 & 99.476 & 76.105 & $.000^{\mathrm{b}}$ \\
& Residual & 103.26 & 79 & 1.307 & & \\
& Total & 401.687 & 82 & & & \\
\hline
\end{tabular}

Sumber: Data diolah, 2018

Tabel 12.

Hasil Uji t

\begin{tabular}{|c|c|c|c|c|c|c|}
\hline \multirow{2}{*}{\multicolumn{2}{|c|}{ Model }} & \multicolumn{2}{|c|}{$\begin{array}{l}\text { Unstandardized } \\
\text { Coefficients }\end{array}$} & \multirow{2}{*}{$\begin{array}{c}\text { Standardized } \\
\text { Coefficients } \\
\text { Beta }\end{array}$} & \multirow[t]{2}{*}{$\mathbf{t}$} & \multirow[t]{2}{*}{ Sig. } \\
\hline & & B & Std. Error & & & \\
\hline \multirow[t]{4}{*}{1} & (Constant) & -6.223 & 2.017 & & -3.085 & .003 \\
\hline & Motivasi & .500 & .131 & .274 & 3.806 & .000 \\
\hline & Gaya Kepemimpinan & .546 & .099 & .414 & 5.532 & .000 \\
\hline & Lingkungan Kerja Fisik & .315 & .078 & .328 & 4.026 & .000 \\
\hline
\end{tabular}

Sumber:Data diolah, 2018

Berdasarkan Tabel 12 hasil uji t dapat dilihat nilai signifikan untuk motivasi yakni 0,000 kurang dari $0,05(0,000<0,05)$ dengan nilai t hitung sebesar 3,806 dan nilai $\mathrm{t}$ tabel yang diperoleh dari tabel $\mathrm{t}$ dengan signifikan 0,05 dan derajat kebebasan $\mathrm{N}-\mathrm{k}=83-4=79$ yakni 1,990 karena t hitung $>\mathrm{t}$ tabel $(3,806$ $>1,990)$. Sehingga $\mathrm{H}_{0}$ ditolak. Dengan kata lain Motivasiberpengaruh positif dan signifikan terhadap semangat kerja pegawai.

Tabel 12 Hasil uji t dapat dilihat nilai signifikan untuk Gaya kepemimpinan transformasional yakni 0,000 kurang dari $0,05(0,000<0,05)$ dengan nilai t hitung sebesar 5,532 dan nilai t tabel yang diperoleh dari tabel t dengan signifikan 0,05 dan derajat kebebasan $\mathrm{N}-\mathrm{k}=83-4=79$ yakni 1,990 karena $\mathrm{t}$ hitung $>\mathrm{t}$ tabel 
Pande Wayan Gede Suandana Putra, Pengaruh Motivasi, Gaya...

$(5,532>1,990)$. Sehingga $\mathrm{H}_{0}$ ditolak. Dengan kata lain Gaya kepemimpinan transformasionalberpengaruh positif dan signifikan terhadap semangat kerja pegawai.

Tabel 12 Hasil uji t dapat dilihat nilai signifikan untuk Lingkungan kerja fisik yakni 0,000 kurang dari $0,05(0,000<0,05)$ dengan nilai t hitung sebesar 4,026 dan nilai t tabel yang diperoleh dari tabel $\mathrm{t}$ dengan signifikan 0,05 dan derajat kebebasan $\mathrm{N}-\mathrm{k}=83-4=79$ yakni 1,990 karena $\mathrm{t}$ hitung $>\mathrm{t}$ tabel $(4,026$ $>$ 1,990) . Sehingga $\mathrm{H}_{0}$ ditolak. Dengan kata lain Lingkungan kerja fisik berpengaruh positif dan signifikan terhadap semangat kerja pegawai.

Hasil penelitian menunjukkan bahwa motivasi berpengaruh positif dan signifikan terhadap semangat kerja yang berarti apabila motivasi semakin baik maka semangat kerja yang dimiliki pegawai Bappeda Litbang Provinsi Bali akan meningkat dan sebaliknya, semakin buruk motivasi maka semangat kerja yang dimiliki pegawai Bappeda Litbang Provinsi Bali akan menurun. Hasil penelitian ini sesuai dengan penelitian sebelumnya yang dilakukan oleh Utamajaya (2015) menemukan bahwa motivasi berpengaruhpositifsignifikan terhadap semangat kerja di Fuji Jaya Motor Gianyar. Penelitian Yordy(2016) di CV. F.A Managementmenyatakan bahwa motivasi mempunyai pengaruh positif dan signifikan terhadap semangat kerja. Penelitian Purnamandari (2014) di Hotel Bali Hyatt Sanur Bali menemukan bahwa motivasi berpengaruh positif terhadap semangat kerja. Penelitian Kusuma dkk. (2017) di Dinas Kesehatan Kaupaten Tabanan mengungkapkan motivasi berpengaruh positif signifikan terhadap semangat kerja pegawai. Penelitian Buroidah (2014) menyatakan dalam 
penelitiannya yaitu motivasi berpengaruh positif signifikan terhadap variabel dependen yaitu Semangat Kerjapada guru dan pegawai SMK Pancasila 1 Kutoarjo.

Hasil penelitian menunjukkan bahwa gaya kepemimpinan transformasional berpengaruh positif dan signifikan terhadap semangat kerja yang berarti apabila gaya kepemimpinan semakin baik maka semangat kerja yang dimiliki pegawai Bappeda Litbang Provinsi Bali akan meningkat dan sebaliknya, semakin buruk gaya kepemimpinan transformasional maka semangat kerja yang dimiliki pegawai Bappeda Litbang Provinsi Bali akan menurun. Hasil penelitian ini sesuai dengan penelitian sebelumnya yang dilakukan oleh Penelitian Rashmi (2015) di tiga Lembaga Pendidikan India menyatakan bahwa gaya kepemimpinan transformasional berpengaruh positifdan signifikan terhadap semangat kerja. Penelitian Purnamandari dkk. (2014) di Hotel Bai Hyatt Sanur Bali menyatakan bahwa gaya kepemimpinan transformasional berpengaruh positifdan signifikan terhadap semangat kerja. Penelitian Paryudi(2014) pada PT. BPR Tish Sukawati Gianyar menyatakan bahwa gaya kepemimpinan transformasional berpengaruh positifdan signifikan terhadap semangat kerja karyawan. Selain itu Penelitian Ari dan Made Surya (2012) di PT. Jamsostek (persero) Cabang Bali I. Penelitian Stewart et al. (2015) di Argosy University Amerika Serikat menyatakan bahwa gaya kepemimpinan transformasional secara parsial menjadi variabel yang mampu meningkatkan semangat kerja.

Hasil penelitian menunjukkan bahwa lingkungan kerja fisik berpengaruh positif dan signifikan terhadap semangat kerja yang berarti apabila lingkngan 
kerja fisik semakin baik maka semangat kerja yang dimiliki pegawai Bappeda Litbang Provinsi Bali akan meningkat dan sebaliknya, semakin buruk lingkungan kerja fisik maka semangat kerja yang dimiliki pegawai Bappeda Litbang Provinsi Bali akan menurun. Hasil penelitian ini sesuai dengan penelitian sebelumnya yang dilakukan oleh Utamjaya(2015) di Fuji Jaya Motor Gianyar dalam penelitinnya menyatakan bahwa lingkungan kerja fisik berpengaruh positif signifikan terhadap semangat kerja pegawai. Penelitian yang dilakukan oleh Suwardika(2015) pada PT. Sang Tunas Sejahtera menyatakan bahwa lingkungankerja fisik secara simultan berpengaruh positif signifikan terhadap semangat kerja pegawai.Penelitian Anwar (2013) pada kantor imigrasi Kota Samarinda menyatakan lingkungn kerja fisik berpengaruh positif terhadap semangat kerja pegawai. Penelitian Paryudi(2014) pada PT. BPR Tish Sukawati Gianyar menyatakan lingkungn kerja fisik berpengaruh positif terhadap semangat kerja. Penelitian Agustina (2016) di SMK Swasta Keahlian Administrasi Perkantoran Kota Semarang menyatakan bahwa terdapat hubungan yang positif signifikan antara lingkungan kerja fisik dengan semangat kerja.

Motivasi merupakan serangkaian sikap dan nilai yang berpengaruh pada individu untuk mencapai hal yang spesifik sesuai dengan tujuan individu, sikap dan nilai ini merupakan suatu yang tidak terlihat yang memberikan kekuatan untuk mendorong individu bertingkah laku dalam mencapai tujuan.Hasil penelitian ini menunjukkan bahwa motivasi berpengaruh terhadap semangat kerja pegawai. Hal ini mengandung implikasi agar kedepannya pimpinan mampu membuat karyawan termotivasi untuk melakukan lebih dari yang diharapkan agar 
dapat meningkatkan semangat kerja karyawan sehingga tujuan dari instansi tercapai.

Kepemimpinan Transformasional merupakan suatu keadaan dimana para pengikut dari seorang pemimpin transformasional merasa adanya kepercayaan, kekaguman, kesetiaan, hormat terhadap pemimpin tersebut, dan mereka termotivasi untuk melakukan lebih dari pada yang awalnya diharapkan mereka, sehingga dapat memacu para karyawan untuk mencapai tujuan dari perusahaan diawali dengan sikap disiplin. Hasil penelitian ini menunjukkan bahwa kepemimpinan transformasional berpengaruh terhadap semangat kerja pegawai. Hal ini mengandung implikasi agar kedepannya pimpinan mampu mempunyai ide kreatif dalam solusi pekerjaan yang diharapkan agar dapat meningkatkan semangat kerja pegawai sehingga tujuan dari instansi tercapai.

Lingkungan kerja fisik merupakan segala sesuatu hal fisik yang terdapat di sekitar lingkungan pegawai yang berpengaruh terhadap pelaksanaan dan penyelesaian tugas dan tanggung jawab yang dibebankan. Hasil penelitian ini menunjukkan bahwa lingkungan kerja fisik berpengaruh terhadap semangat kerja pegawai. Hal ini mengandung implikasi agar lingkungan kerja fisik yang ada di instansi harus berjalan dengan baik agar proses bekerja di dalam instansi dapat berjalan dengan baik tanpa permasalahan yang dapat mengakibatkan tidak nyamannya pegawai dalam bekerja.

Terdapat keterbatasan yang mempengaruhi kondisi dari penelitian yang dilakukan. Adapun keterbatasan dalam penelitian ini yaitu jumlah responden hanya 83 orang pegawai dan hanya di lingkungan Bappeda Litbang Provinsi 
Pande Wayan Gede Suandana Putra, Pengaruh Motivasi, Gaya...

Bali, sehingga hasil penelitian ini hanya dapat diterapkan dilingkungan kerja Bappeda Litbang Provinsi Bali dan tidak dapat digeneralisasi pada lingkungan perusahaan ataupun instansi lain.

Faktor-faktor yang mempengaruhi semangat kerja dalam penelitian ini hanya terdiri dari tiga variabel, yaitu motivasi, gaya kepemimpinan transformasional, dan lingkungan kerja fisik, sedangkan masih banyak faktor lain yang mempengaruhi semangat kerja.

\section{SIMPULAN}

Motivasi memiliki pengaruh positif dan signifikan terhadap semangat kerja pegawai di Bappeda Litbang Provinsi Bali. Hal ini menunjukan semakin baik motivasi yang di berikan oleh pihak Bappeda Litbang Provinsi Bali maka semangat kerja pegawai juga akan meningkat.

Gaya kepemimpian transformasional memiliki pengaruh positif dan signifikan terhadap semangat kerja pegawai di Bappeda Litbang Provinsi Bali. Hal ini menunjukan semakin baik gaya kepemimpinan transformasional yang di berikan oleh pimpinan Bappeda Litbang Provinsi Bali maka semangat kerja pegawai juga akan meningkat.

Lingkungan kerja fisik memiliki pengaruh positif dan signifikan terhadap semangat kerja pegawai di Bappeda Litbang Provinsi Bali. Hal ini menunjukan semakin baik lingkungan kerja fisik yang di berikan oleh pihak Bappeda Litbang Provinsi Bali maka semangat kerja pegawai juga akan meningkat.

Saran yang dilandasi berdasarkan hasil analisis penelitian yang dapat dilihat dari deskripsi variabel penelitian dengan nilai yang paling rendah dari masing- 
masing variabel yaitu motivasi, gaya kepemimpinan transformasional, dan lingkungan kerja fisik adalah pimpinan Bappeda Litbang Provinsi Bali sebaiknya memberikan pegawai pemikiran di saat pegawai melakukan kesalahan contohnya seperti memberikan ide atau masukan agar pegawai memiliki inisiatif di dalam memperbaiki pekerjaan menjadi lebih baik dan tujuan instansi akan tercapai.

Pimpinan harus lebih sering mendengarkan keluhan pegawai contohnya seperti pada saat pegawai memberikan keluhan-keluhan di dalam kantor ataupun permasalahan tugas-tugas yang diberikan pimpinan mendengarkan dan memberikan solusi agar dapat menimbulkan rasa nyaman dari atasan maupun bawahan pada saat melakukan pekerjaan.

Cahaya di setiap ruangan kerja sebaiknya lebih memadai agar produktivitas pegawai di dalam melakukan pekerjaan meningkat demi tercapainya efektifitas bekerja pegawai Bappeda Litbang Provinsi Bali.

\section{REFERENSI}

Anteja, I Gusti. (2014). Pengaruh Kepemimpinan Komunikasi dan Lingkungan Kerja Terhadap Semangat Kerja Pegawai Pada PT. Angkasa Pura 1 Divisi Komersial Bali. E-Jurnal Manajemen Universitas Udayana, v. 3, n. 2. ISSN 2302-8912.

Ardana dkk. (2012). Manajemen sumber daya manusia. Edisi ke 1. Graha Ilmu Yogyakarta.

Arunchand, C H dan Ramanathan, Hareesh N. (2013). Organizational Culture and Employee Morale: A Public Sector Enterprise Experience. Journal of Strategic Human Resource Management; New Delhi Vol. 2, Iss. 1, 18.

Bass, B. M. (1985). Leadership and Performance Beyond Expectations. New Yorl: The Free Press.

Buroidah, Titik. (2014). Pengaruh Motivasi Terhadap Semangat Kerja Pada Guru Dan Karyawan Smk Pancasila 1 Kutoarjo. Jurnal Pendidikan Ekonomi. Vol 3, No 1 
Dewi, Dimika Sari dan Ni Wayan Mujiati. (2015). Pengaruh The Big Five Personality dan Kepemimpinan Transformasional Terhadap Kinerja Karyawan di Karma Jimbaran Villa. E-Jurnal Manajemen Universitas Udayana, 4(4), hal: 930-942.

George dan Jones, (2005), Understanding and Managing Organizational. Behavior 4th Edition, Pearson Prentice Hall.

Gorda, I Gusti Ngurah. (2004). Manajemen Sumber Daya Manusia. Cetakan Kedua. Denpasar : Astabarata Bali

Gunawan, Indra I Kadek dan I Gusti Salit Ketut Netra. (2017). Pengaruh Kepemimpinan Transformasional dan Komitmen Organisasional Terhadap Organizational Citizenship Behavior Karyawan. E-Jurnal Manajemen Universitas Udayana, 6(4), hal: 2133-2160

Ljungholm, Doina Popescu. (2014). Transformational Leadership Behavior in Public Sector Organizations. Contemporary Readings in Law and Social Justice, 6(1), pp: 76-81.

Ngambi, H.C. (2011). The Relationship Between Ledership And Employee Morale In Higher Education. Journal Of Business Management, 5(3)H 762-776.

Nitisemito, A.S. (2000). Manajemen Personalia: Manajemen Sumber Daya Manusia. Ghalia Indonesia, Jakarta.

Northouse, Peter G. (2013). Kepemimpinan Teori dan Praktek. Edisi Keenam. Jakarta: Indeks

Paryudi, Made; Ardana, I Komang. (2014). Pengaruh Gaya Kepemimpinan, Komunikasi Dan Lingkungan Kerja Fisik Terhadap Semangat Kerja Karyawan Pada Pt. Bpr Tish Sukawati Gianyar. E-Jurnal Manajemen Universitas Udayana, [S.L.], V. 3, N. 1. Issn 2302-8912.

Prabu, Anwar. (2005). Pengaruh Motivasi Terhadap Kepuasan Kerja Pegawai Badan Koordinasi Keluarga Berencana Nasional Kabupaten Muara Enim, Jurnal Manajemen \& Bisnis Sriwijaya Vol. 3 No 6.

Purnamandari, Ni Wayan Quiena; Suana, I Wayan. (2014). Analisis Faktor Motivasi, Kepemimpinan, Lingkungan Kerja, Komunikasi, Penempatan Karyawan, dan Kompensasi yang Mempengaruhi Semangat Kerja Karyawan Hotel Bali Hyatt Sanur Bali. E-Jurnal Manajemen Universitas Udayana. vol 3, no 8. ISSN 2302-8912.

Rahmi, B. Maptuhah. (2014). Pengaruh Kepemimpinan Transformasional Terhadap Organizational Citizenship Behavior dan Komitmen Organisasi Dengan Mediasi Kepuasan Kerja. E-Jurnal Manajemen Universitas Udayana, 3(2), hal: 330-350. 
Robbins, S.P dan Judge T.A. (2015). Perilaku Organisasi. Jakarta: Salemba Empat.

Sedarmayanti. (2001). Sumber Daya Manusia dan Produktivitas Kerja. Mandar Maju. Bandung.

Sedarmayanti. (2009). Sumber Daya Manusia dan Produktivitas Kerja. Bandung: CV Mandar Maju.

Siagian, Sondang P, (2007), Manajemen Sumber Daya Manusia, Edisi Pertama, Cetakan Keempatbelas, Penerbit Bumi Aksara, Jakarta.

Stewart-Banks, Kuofie, Hakim, Branch, Robert. (2015). Education Leadership Styles Impact on Work Performance and Morale of Staff. Journal of Marketing and Management, Beverly Hills. Vol. 6, Iss. 2, 87-105.

Surya Rashmi Rawat. (2015). Impact of Transformational Leadership over Employee Morale and Motivation. Indian Journal of Science and Technology, Vol 8(S6)

Tohardi, (2006), Pemahaman Praktis Manajemen Sumber Daya Manusia, Universitas Tanjung Pura, Mandar Maju, Bandung

Utamajaya. (2015). Pengaruh Motivasi, Komunikasi, Serta Lingkungan Kerja Fisik Terhadap Semangat Kerja Karyawan Pada Fuji Jaya Motor Gianyar. E-Jurnal Manajemen Universitas Udayana, v. 4, n. 6. ISSN 2302-8912.

Yordy Kusuma Wisnu. (2016). Pengaruh Motivasi Kerja Dan Insentif Terhadap Semangat Kerja Karyawan Cv. F.A Management. E-Jurnal Ilmu dan Riset Manajemen : Volume 5, Nomor 2, ISSN : 2461-0593 